\title{
'PEER MEDIATED BUDDY PROGRAM' UNTUK MENINGKATKAN KOMPETENSI SOSIAL SISWA DENGAN AUTISME di SEKOLAH INKLUSI
}

\author{
Suprihatin \\ Fakultas Ilmu Pendidikan, Universitas Negeri Jakarta \\ E-mail: kehoksuprihatin@yahoo.com
}

\begin{abstract}
This research aims to know application 'peer mediated buddy program' to student with autisme in the inclusion school which can improved social student competence with autis. This research used descriptive qualitative Research with used friend who training and piring to helm student with autis can make them socializing in or out classes. Regarding observation Result shows for the First Time, the volunteer felt confused to keep in touch with autism student. Because of the volunteer difficult to communicated with them, because One of the students still difficult to understand what he is talking about. He jus Said with duplicated what Hie friend Said. But, the attitude intensity decline like suddenly running to teacher who explaining a subject in front of the class. This indicates a successfull Action which is given to student with autism.
\end{abstract}

Keywords: per mediated buddy program, social student autism competency, inclusion school.

\begin{abstract}
Abstrak
Penelitian ini bertujuan untuk mengetahui apakah dengan diterapkannya 'peer mediated buddy program' kepada siswa dengan autisme disekolah inklusi akan dapat meningkatkan kompetensi sosial siswa dengan autisme. Penelitian ini adalah penelitian deskriptif kualitatif dengan menggunakan teman sebaya yang sudah dilatih dan sengaja dipasangkan untuk membantu siswa dengan autisme bersosialisasi baik di dalam maupun di luar kelas. Berdasarkan hasil pengamatan selama tindakan berlangsung, tampak terlihat bahwa sukarelawan masih agak kebingungan pada awalnya ketika berinteraksi dengan siswa dengan autisme. Hal ini dikarenakan kendala komunikasi diantara mereka, salah satu siswa dengan autisme dalam penelitian ini memang cara berkomunikasinya masih sulit dipahami. dia berkomunikasi seperti membeo hanya menirukan kata-kata yang diucapkan oleh teman sukarelawannya. Namun ada penurunan intensitas perilaku yang kurang menyenangkan seperti berlari secara tiba-tiba ke arah guru yang sedang menerangkan pelajaran di depan kelas. Hal ini menunjukkan adanya keberhasilan tindakan yang diberikan kepada siswa dengan autisme tersebut.
\end{abstract}

Kata kunci: peer mediated buddy program, kompetensi sosial siswa autisme, sekolah inklusi

\section{PENDAHULUAN}

Pendidikan untuk semua telah memberikan dampak yang cukup nyata bagi sistem pendidikan di Indonesia terutama bagi sekolah dasar. Dampak ini terlihat pada beberapa sekolah dasar diberbagai wilayah terutama DKI dan Jawa Barat yang sudah mencanangkan dirinya menjadi sekolah inklusi. Sekolah-sekolah tersebut menerima dan mendidik tidak hanya anak biasa pada umumnya tetapi juga anak berkebutuhan khusus seperti tunanetra, tunarungu, tuna-grahita, anak dengan autisme dan lain-lain. Hal ini menunjukkan bahwa sekolah-sekolah mulai peduli kepada anak-anak yang berkebutuhan khusus yang mungkin tidak bisa bersekolah di Sekolah Luar Biasa karena alasan-alasan tertentu.

Kegiatan belajar dan pembelajaran di sekolah inklusi tidak jauh berbeda dengan sekolah lain pada umumnya. Semua anak baik yang berkebutuhan khusus terutama anak dengan autisme belajar dan 
bermain bersama dengan teman sebaya mereka di kelas yang sama dengan guru yang sama. Mereka mengerjakan tugas yang hampir sama dengan teman mereka, membentuk kelompok kerja dan belajar bersama-sama di dalam maupun di luar kelas. Namun, ada hal-hal tertentu yang dibedakan oleh guru seperti jumlah materi yang diberikan dan penilaian akhir.

Dalam pembelajaran di kelas, anakanak berkebutuhan khusus terutama anakanak dengan autisme, terkadang memuncul-kan tindakan di luar dugaan yang dapat mengganggu teman atau gurunya. Tindakan-tindakan tersebut antara lain seperti tiba-tiba lari menuju papan tulis padahal guru sedang menerangkan dan menirukan kata-kata guru sama persis seperti yang sedang diucapkan oleh guru.

Ketika waktu istirahat, pada umumnya anak berkebutuhan khusus terutama anak dengan autisme, mereka cenderung menyendiri, berdiri sendiri didekat pedagang makanan atau hanya berlarian sambil mengomel entah apa yang dibicarakan. Terkadang mereka juga hanya duduk dikelas tidak melakukan apapun. Bahkan terkadang ada yang hanya bermain dengan orang tua atau pengasuhnya saja. Sedangkan teman-teman mereka asik bermain bersama seperti bermain sepak bola, petak umpet dan permainanpermainan lain yang membutuh-kan anggota yang banyak dalam memainkannya.

Hal-hal demikian menunjukkan bahwa sekolah masih kurang peduli dengan kemampuan sosialisasi anak-anak berkebutuhan khusus. Sekolah masih lebih banyak perhatian pada kegiatan akademik dikelas saja sedangkan kegiatan sosialisasi anak berkebutuhan khusus mungkin masih dianggap sepele padahal untuk anak-anak penyandang autisme hal ini tidak akan terjadi secara otomatis pada diri mereka jika mereka tidak diajarkan secara khusus karena kegiatan sosial merupakan kesulitan mereka yang nyata.
Sekolah yang menerima mereka sebagai murid harus mampu membantu anak-anak dengan kebutuhan khusus untuk bersosialisasi. Dalam hal ini, pihak sekolah disarankan ikut melakukan pengawasan ketika murid-murid sedang beristirahat sehingga anak-anak dengan autisme bisa berbaur dan bersosialisasi dengan temanteman sebaya mereka yang tidak mengalami gangguan sosialisasi. Jika guru melakukan tugas ini mungkin guru akan kehabisan waktu dan tidak bisa beristirahat tetapi jika guru bisa memberdayakan murid-murid yang lain, kemungkinan terjadi adanya simbiosis mutualisme yang nyata. Tetapi kemungkinan ada muridmurid yang tidak mau dilibatkan dalam kegiatan sosialisasi siswa ber-kebutuhan khusus terutama autisme dengan alasan yang jelas seperti takut kepada anak tersebut, susah diajak ngomong, atau takut dipukul oleh siswa yang autis.

Fakta yang lain menunjukkan bahwa tidak semua guru maupun staf yang ada disekolah mengerti dan memahami kebutuhan khusus masing-masing siswa berkebutuhan khusus yang ada dikelasnya. Sebagian besar guru dan staf mengerti sebatas nama kebutuhan khusus yang dimiliki oleh masing-masing anak tetapi belum mengerti apa yang harus dikerjakan, diberikan dan dilakukan dengan kebutuhan khusus masing-masing siswa. Hal ini dikarenakan pada umumnya guru bukanlah guru dengan dasar pendidikan luar biasa. Mereka pada umumnya adalah guru kelas ataupun guru bidang studi dan terkadang di sekolah tersebut juga belum ada guru pendidikan khusus yang bisa membagi informasi tentang kekhususan masingmasing siswa berkebutuhan khusus.

Berdasarkan latar belakang seperti di atas, rumusan permasalahan secara umum dalam penelitian ini adalah: Apakah penerapan 'Peer Mediated Buddy Program' akan mampu meningkatkan kompetensi sosial siswa penyandang autisme di sekolah inklusi? 
Penelitian ini bertujuan untuk Mengetahui ada atau tidaknya peningkatan kompetensi sosial siswa dengan autisme setelah mengikuti 'peer mediated buddy program'.

\section{Pengertian Pendidikan Inklusi dan Sekolah Inklusi}

Pendidikan inklusif adalah pendidik-an yang mengakomodasi semua anak tanpa memandang kondisi fisik, intelektual, emosional, sosial, maupun kondisi lainnya. Pendidikan yang memungkinkan semua anak belajar berasama-sama tanpa memandang perbedaan yang mungkin ada pada mereka. Pendidikan yang berupaya memenuhi kebutuhan setiap anak. Pendidikan yang dilaksanakan tidak hanya di sekolah formal, tetapi juga di lembaga pendidikan dan tempat lain.

Menurut Tim Pendidikan Inkulsif Jawa Barat (2003: 4) mendefinisikan Pendidikan inklusif sebagai layanan pendidikan yang semaksimal mungkin mengakomodasi semua anak didik termasuk anak yang berkebutuhan khusus di sekolah atau lembaga pendidikan atau tempat lain (diutamakan yang terdekat dengan tempat tinggal anak didik) bersama teman-teman sebayanya dengan memperhatikan perbeda-annya.

Sunanto et all. (2004: 3) menjelaskan mengenai pendidikan inklusif sebagai berikut:

Pendidikan inklusif adalah pendidikan yang memberikan layanan kepada setiap anak, tidak terkecuali. Pendidikan yang memberikan layanan terhadap semua anak tanpa memandang kondisi fisik, mental, intelektual, sosial, emosi, ekonomi, jenis kelamin, suku, budaya, tempat tinggal, bahasa dan sebagainya. Semua anak belajar bersama-sama, baik di kelas/sekolah formal maupun non-formal yang berada di tempat tinggalnya yang disesuaikan dengan kondisi dan kebutuhan masingmasing anak.
Dalam seting pengajaran dengan karakteristik inklusif guru diharapkan mampu memahami bahwa setiap siswa memiliki perbedaan baik dari kemampuan, kecerdasan, konsentrasi, minat, motivasi. Dari keberagaman siswa tersebut guru hendaknya mampu memahami kebutuhan siswa secara individual, walaupun mengajar di sekolah reguler secara klasikal. Guru harus mampu memberi dukungan dan strategi pengajaran khusus bagi siswasiswa yang membutuhkan bantuan, serta melaksanakan penilaian yang sesuai dengan kemampuan siswa dan berdasarkan hasil asesmen.

Menjadi sekolah yang terbuka (welcoming) menuntut berbagai persiapan yang harus dilakukan. Nilai penting dalam melaksanakannya adalah ditumbuhkembang-kannya sikap positif dan menghargai serta menerima adanya perbedaan individu dari siswa. Dalam hal ini sekolah lebih dituntut untuk dapat mengembangkan kondisi yang lebih kondusif dalam pembelajaran yang berpusat pada siswa/anak dan memandang perbedaan sebagai suatu yang normal/biasa serta perlu penanganan secara adil didasarkan kebutuhannya.

"Pendidikan inklusif" berarti bahwa sebagai guru bertanggung jawab untuk mengupayakan bantuan dalam menjaring dan memberikan layanan pendidikan pada semua anak dari otoritas sekolah, masyarakat, keluarga, lembaga pendidikan, layanan kesehatan, pemimpin masyarakat dan lainlain. (Direktorat PLB, Braillo Norway dan UNESCO: 2004).

Di beberapa tempat, semua anak mungkin masuk sekolah, tetapi masih terdapat beberapa anak yang terpisahkan dari keikutsertaan dalam pembelajaran di kelas. Misalnya peserta didik yang menggunakan bahasa ibu yang berbeda dengan buku-buku pelajaran dan bacaan yang digunakan, tidak pernah diberi kesempatan untuk aktif dalam kelas, memiliki masalah gangguan penglihatan dan atau mendengar; atau tidak pernah 
mendapatkan bantuan ketika mengalami hambatan belajar. Guru bertanggung jawab untuk menciptakan lingkungan belajar yang kondusif agar seluruh peserta didik dapat dan ingin belajar serta merasa terlibat di kelas dan di sekolah (Dinas Pendidikan Provinsi Jawa Barat: 2005).

Pendidikan inklusif adalah suatu upaya secara sadar dari fihak tertentu untuk mengembangkan potensi individu seoptimal mungkin. Upaya ini dilaksanakan di lingkungan tempat tinggal peserta didik. Kompetensi dan materi pembelajaran disesuaikan dengan potensi/ kebutuhan individu yang bersangkutan (Kepala dinas Pendidikan Provinsi Jawa Barat: 2003).

Sekolah perlu berupaya menjadi sekolah yang "ramah terhadap anak". Sekolah yang "ramah" terhadap anak merupakan sekolah di mana anak memiliki hak untuk belajar mengembangkan potensinya seoptimal mungkin di dalam lingkungan yang aman dan terbuka. Tujuannya untuk meningkatkan partisipasi dan pembelajaran pada setiap anak, daripada hanya memfokuskan pada mata pelajaran dan ujian saja. Menjadi "ramah" terhadap anak itu penting, tapi belum bermakna apabila keterlibatan dan partisipasi dalam pembelajaran itu tidak tercipta dengan baik.

Anak datang ke sekolah untuk belajar, tapi sebenarnya guru juga ikut belajar, misalnya guru memperoleh hal yang baru tentang cara mengajar yang lebih efektif dan menyenangkan agar seluruh peserta didik dapat belajar secara optimal (misalnya dalam membaca, menulis dan berhitung yang sesuai dengan kebutuhannya). Lingkungan pembelajaran yang ramah ialah ramah kepada anak dan guru, berarti: Anak dan guru belajar bersama sebagai suatu komunitas belajar, menempatkan anak sebagai pusat pembelajaran, mendorong partisipasi aktif anak dalam belajar, dan guru memiliki minat untuk memberikan layanan pendidikan yang terbaik.
Semua anak memiliki hak untuk belajar, tanpa memandang perbedaan fisik, intelektual, sosial, emosi, bahasa atau kondisi lainnya, seperti yang ditetapkan dalam Konvensi Hak Anak di mana semua pemerintah di dunia menandatanganinya. di Indonesia tercantum dalam UU No.23 tahun 2002 tentang perlindungan anak.

Guru perlu mengetahui bagaimana cara mengajar anak dengan latar belakang dan kemampuan yang beragam. Peningkatan kemampuan ini dapat dilakukan dengan berbagai cara seperti: pelatihan, tukar pengalaman, lokakarya, membaca buku, mengeksplorasi/menggali sumber lain kemudian mempraktekkannya di dalam kelas.

Dalam "Sekolah Inklusif", setiap orang berbagi visi yang sama tentang bagaimana anak harus belajar, bekerja dan bermain bersama. Mereka yakin, bahwa pembelajaran hendaknya inklusif, adil dan tidak diskriminatif, sensitif terhadap semua budaya, serta relevan dengan kehidupan sehari-hari anak dan keluarganya. Guru, admi-nistrator, dan peserta didik menghargai per-bedaan kemampuan, karakteristik, sosial ekonomi dan latar belakang penggunaan bahasa. Pendidikan Inklusif mengajarkan keca-kapan hidup dan gaya hidup sehat, agar pe-serta didik dapat menggunakan informasi yang diperoleh untuk melindungi diri dari penyakit dan bahaya. Terlebih lagi, di dalam "Pendidikan Inklusif" tidak ada kekerasan terhadap anak, pemukulan atau hukuman fisik.

Dalam sekolah Inklusif mendorong guru, administrator sekolah, anak, keluarga dan masyarakat untuk membantu pembelajaran anak. Misal: di kelas, peserta didik beserta guru bertanggung jawab kepada pembelajaran dan secara aktif berpartisipasi di dalamnya. Belajar berkaitan dengan materi apa yang dibutuhkan dan bermakna dalam kehidupannya. "Pendidikan Inklusif" juga mempertimbangkan kebutuhan, minat, dan keinginan kita sebagai guru. Ini berarti 
memberikan kesempatan kepada kita untuk belajar bagaimana mengajar yang lebih baik.

Sekolah Inklusif merupakan perkembangan terbaru model pendidikan bagi anak berkebutuhan khusus yang secara formal ditegaskan dalam pernyataan Salamanca pada Konferensi Dunia tentang Pendidikan Berkelainan bulan Juni 1994, bahwa "Prinsip mendasar dari pendidikan inklusif adalah selama memungkinkan, semua anak seyogyanya belajar bersamasama tanpa memandang kesulitan ataupun perbedaan yang mungkin ada pada mereka".

Kaitannya dengan Pendidikan Inklusif, Stainback (Budiyanto, 2005:18) memberikan batasan yang relatif lebih spesifik dalam konteks seting persekolahan-nya, yaitu sekolah yang menampung semua siswa di kelas yang sama. Sekolah ini menyediakan program pendidikan yang layak, menantang, tetapi sesuai dengan kemampuan dan kebutuhan setiap siswa, maupun bantuan dan dukungan yang dapat diberikan oleh para guru agar anak-anak berhasil. Lebih dari itu, sekolah inklusif juga merupakan tempat setiap anak dapat diterima, menjadi bagian dari kelas tersebut, dan saling membantu dengan guru dan teman sebayanya, maupun anggota masyarakat lain agar kebutuhan individualnya dapat terpenuhi.

Salah satu karakteristik terpenting dari Sekolah Inklusif adalah satu komunitas yang kohesif, menerima dan responsive terhadap kebutuhan individual siswa. Untuk itu, Sapon Shevin (Sunardi: 2002) mengemukakan lima profil pembelajaran di sekolah inklusif, yaitu:

1. Pendidikan Inklusif berarti menciptakan dan menjaga komunitas kelas yang hangat, menerima keanekragaman, dan menghargai perbedaan.

2. Mengajar kelas yang hetorogen memerlukan perubahan pelaksanaan kurikulum secara mendasar.
3. Pendidikan Inklusif berarti menyiapkan dan mendorong guru untuk mengajar secara interaktif.

4. Pendidikan Inklusif berarti penyediaan dorongan bagi guru dan kelasnya secara terus menerus dan penghapusan hambatan yang berkaitan dengan isolasi profesi.

5. Dengan pendidikan inklusif berarti melibatkan orang tua secara bermakna dalam proses perencanaan begitu pula dengan keterlibatan masyarakat sekitarnya.

Hal ini membawa implikasi pada ketercapaian indikator keberhasilan pendidikan inklusif pada suatu sekolah yaitu adanya saling menghargai, toleransi, menjadi bagian suatu masyarakat, diberikan kesempatan untuk mengembangkan keterampilan dan bakat, saling membantu, belajar dari satu sama lain, dan membantu orang untuk menolong dirinya sendiri dan masyarakatnya. di bawah ini dikemukakan bagan karakteristik lingkungan inklusif yaitu lingkungan pembelajaran yang ramah. (Direktorat PLB, Braillo Norway dan UNESCO: 2004).

\section{Pengertian Autisme}

Istilah Autisme berasal dari kata "Autos" yang berarti diri sendiri "Isme" yang berarti suatu aliran. Berarti suatu paham yang tertarik hanya pada dunianya sendiri. Autisme juga suatu keadaan dimana seseorang anak berbuat semaunya sendiri baik cara berfikir maupun berperilaku. Keadaan ini mulai terjadi sejak usia masih muda, biasanya sekitar usia 2-3 tahun.

Menurut Rimland (Ginanjar, 2007) autisme adalah gangguan yang disebabkan oleh kesal.ahan pada syaraf otak. Menurut penelitian terbaru, autisme lebih banyak disebabkan karena faktor gen si penyandang-nya (Chakrabarti, 2009) Autisme bisa mengenai siapa saja, baik sosioekonomi mapan maupun kurang, 
anak-anak ataupun dewasa dan semua etnis (Faisal Yatim dalam Kasih, 2006).

Autistik adalah suatu gangguan perkembangan yang kompleks menyangkut komunikasi, interaksi sosial dan aktivitas imajinasi. Gejalanya mulai tampak sebelum anak berusia 3 tahun. Bahkan pada autistik infantil gejalanya sudah ada sejak lahir. Penyandang autisme seolah-olah hidup dalam dunianya sendiri. Istilah autisme baru diper-kenalkan sejak tahun 1913 oleh Leo Kanner, sekalipun kelainan itu sudah ada sejak berabad-abad yang lampau. Autisme bukan suatu gejala penyakit tetapi berupa sindroma (kumpulan gejala) dimana terjadi penyim-pangan perkembangan sosial, kemampuan berbahasa, dan kepedulian terhadap sekitar sehingga anak autisme seperti hidup dalam dunianya sendiri (Handojo,2003).

\section{Karakteristik Siswa dengan Autisme Komunikasi}

Perkembangan bahasa penyandang autis sangat lambat atau bahkan tidak ada tanda-tanda perkembangan sama sekali. Anak penyandang autis ketika dipanggil jarang sekali merespon panggilan. Mereka tampak seperti tuli dan sulit berbicara, atau pernah berbicara tapi kemudian sirna hilang sama sekali.

Ada juga penyandang autis yang mampu berbicara tapi terkadang kata-kata yang digunakan kurang pas atau bahkan tidak sesuai dengan artinya. Kebanyakan dari mereka yang mampu berbicara, mereka menggunakan bahasa secara harfiah mereka kurang mengerti atau bahkan tidak mengerti sama sekali arti atau makna katakata secara konotatif.

Sering sekali para penyandang autis hanya mengoceh berulang-ulang tanpa arti, dengan bahasa yang tak dapat dimengerti orang lain. Kebanyakan dari mereka tidak menggunakan bicara untuk alat berkomunikasi melainkan dengan gerakangerakan tangan misalnya dengan menarik tangan orang dewasa ketika menginginkan sesuatu.
Banyak sekali para penyandang autis yang senang meniru atau membeo (echolalia) yaitu mengulangi keseluruhan kata-kata yang diucapkan oleh orang lain yang mengajaknya berbicara. diantara merekapun banyak yang senang meniru, mampu menghafal secara tepat kata-kata dalam lagu atau nyanyian yang didengarnya tanpa mengerti artinya.

\section{Interaksi sosial}

Dalam hal interaksi sosial, kita akan jarang sekali melihat para penyandang autisme ini dalam lingkungan yang ramai karena mereka lebih suka menyendiri. Hal ini disebabkan karena mereka kurang mampu mengatur masuknya stimulus dari berbagai macam sensor yang dimilikinya sehingga lingkungan di luar dirinya dianggap sebagai dunia asing baginya (Jones, 2002).

Seringkali penyandang autisme tidak ada atau sedikit kontak mata, atau menghindar untuk bertatapan sehingga seringkali orang lain yang tidak mengetahui keadaan ini menganggap mereka kurang sopan ketika berbicara. Menurut Jones (2002) hal ini disebabkan karena mereka kurang mampu mengolah dua macam proses yang terjadi dalam waktu yang bersamaan yaitu mendengar dan melihat. Jika penyandang autis melihat orang yang mengajaknya berbicara, maka dia kurang mampu mengolah pesan yang diterimanya melalui pendengaran demikian juga sebaliknya.

Para penyandang autis seringkali tidak tertarik untuk bermain bersama teman, bila diajak bermain, ia tidak mau dan menjauh. Hal ini sekali lagi disebabkan oleh ketidakmampuannya dalam merespon ling-kungan sekitarnya.

\section{Gangguan sensoris}

Kebanyakan para penyandang autisme sangat sensistif terhadap sentuhan, seperti tidak suka dipeluk, disentuh oleh orang lain walaupun itu ibunya sendiri. Apabila ini terjadi mereka akan merasa 
tidak nyaman bahkan terkadang akan berontak dengan cara menangis ataupun memukul orang yang berusaha mendekatinya. Dan mereka juga kurang sensitif terhadap rasa sakit. Seringkali mereka menyakiti diri sendiri dengan cara memukul-mukul kepala, membenturkan bagian belakang kepala ke tembok ataupun membenturkan bagian jidat ke lantai. Hal ini mereka gunakan sebagai alat mempertahankan diri maupun protes terhadap apa yang tidak mereka kehendaki.

\section{Pola bermain}

Pola bermain para penyandang autisme, tidak sama seperti anak-anak pada umumnya. Jika bermain dengan bendabenda, mereka cenderung akan menyusun benda-benda tersebut menurut pola tertentu yang mereka sukai. Jika bermain dengan mobil-mobilan mereka cenderung hanya akan memutar salah satu roda pada mobil tersebut. Hal ini dikarenakan mereka tidak mampu berimajinasi tentang bagaimana memainkan mobil mobilan yang dimilikinya.

Kecenderungan mereka yang lain adalah menyenang benda-benda yang berputar, seperti kipas angin, roda sepeda dan mesin cuci. Menurut Jones (2002) hal ini berhubungan dengan kemampuan imajinatif dan berpikir kreatif mereka dalam menggunakan permainan, dimana dalam diri mereka kedua hal tersebut sangatlah kurang adanya. Jika mereka mempunyai sesuatu yang sangat disenanginya, kemungkinan mereka tidak akan melepaskannya begitu saja. Mereka akan terus bersama barang tersebut di mana pun mereka berada.

\section{Perilaku}

Dalam hal tingkah laku mereka dapat berperilaku berlebihan (hiperaktif) atau kekurangan (hipoaktif). Ketika mereka hiperaktif, beberapa dari mereka akan berjalan-jalan terus, tidak mau duduk diam di tempat duduk yang disediakan. Bagi mereka yang hipoaktif, mereka cenderung diam bermalas-malasan tanpa mau melakukan apa pun yang ditugaskan. Seringkali juga mereka menampak kan wajah yang kusut, mengantuk dan tertidur di kelas.

Pada umumnya para penyandang autisme tidak menyukai perubahan. Perubahan dianggapnya sebagai ancaman yang akan membuyarkan pemikiran mereka terhadap hal-hal yang akan dilakukan. Hal ini disebabkan karena ketidakmampuan mereka memprediksi apa yang akan terjadi selanjut-nya. Maka ketika hal yang sudah tertata dengan rapi dalam benaknya berubah sedikit saja, mereka terkadang meresponnya dengan cara yang berlebihan seperti tantrum atau menyakiti diri sendiri maupun orang lain.

\section{Kompetensi Sosial}

Pengertian dan pengelompokan tentang life skill banyak dikemukakan oleh para ahli dan lembaga yang memiliki otorita di bidang pendidikan, pelatihan, maupun kesehatan. Depdiknas pada tahun 2002, dengan berdasar pada berbagai pendapat ahli tentang life skill telah menyimpulkan bahwa life skill merupakan kecakapan yang dimiliki seseorang untuk berani menghadapi problema hidup dan kehidupan dengan wajar tanpa merasa tertekan, kemudian secara proaktif dan kreatif mencari serta menemukan solusi untuk pemecahannya (Depdiknas, 2002).

Broling membagi life skill menjadi tiga kelompok kecakapan, yaitu:
a. Daily living skill (kecakapan hidup sehari-hari)
b. Personal/social skill (kecakapan pribadi/ social)
c. Occupational skill (kecakapan bekerja)

WHO mengelompokkan life skill menjadi lima aspek, yaitu:
a. Self awareness atau personal skill (kecakapan mengenal diri atao kecakapan pribadi)
b. Social skill (kecakapan social)
c. Thinking skill (kecakapan berpikir) 


\section{d. Academic skill (kecakapan akademik)}

e. Vocational skill (kecakapan kejuruan)

Berdasar kedua pengelompokan ini, dapat dilihat bahwa social skill merupakan bagian dari life skill. Dalam penelitian ini, social skill yang merupakan salah satu bagian dari life skill dinyatakan dengan istilah social life skill. Social skill atau social life skill menurut Morgan (dalam Cartledge dan Milburn, 1995) adalah kemampuan untuk menyatakan dan berinteraksi secara positif dengan orang lain.

Rogers dan Ross (dalam Brewer, 1995) menggambarkan social skill sebagai kemampuan untuk menilai apa yang sedang terjadi dalam suatu situasi sosial, keterampilan untuk memahami dan menginterpretasikan secara tepat tindakan dan kebutuhan anak-anak dalam kelompok pada saat mereka bermain; dan keterampilan untuk membayangkan beberapa kemungkin-an alternatif tindakan dan memilih salah satu yang paling memadai.

Dalam kurikulum untuk anak prasekolah, Curtis (1988) menyatakan bahwa social skill merupakan strategi yang digunakan ketika orang berusaha memulai ataupun mempertahankan suatu interaksi sosial. Hal yang sama juga dinyatakan oleh Saifer (1997) maupun Combs dan Sloby (dalam Cartledge dan Milburn, 1995).

Kelly (dalam Ramdhani, 1991) mengatakan bahwa social skill adalah keterampilan yang diperoleh individu melalui proses belajar yang digunakan dalam berhubungan dengan lingkungannya dengan cara baik dan tepat. Bertujuan untuk mendapatkan pengukuh dari hubungan interpersonal yang dila-kukan dan menolak hadirnya suatu keadaan yang tidak menyenangkan.

Dari beberapa batasan yang dikemukakan ini, dapat disimpulkan bahwa social life skill atau social skill adalah keterampilan atau strategi yang digunakan untuk memulai ataupun mempertahankan suatu hubungan yang positif dalam interaksi sosial, yang di-peroleh melalui proses belajar, dan bertujuan untuk mendapatkan reward atau re-inforcement dalam hubungan interpersonal yang dilakukan, dan menolak punishment atau hadirnya suatu keadaan yang tidak menyenangkan.

Menurut pengertian operasional yang dikembangkan oleh Depdiknas, social skill meliputi:

a. kecakapan kerja sama

b. bertenggang rasa, dan

c. tanggung jawab sosial

Curtis (1988) mengatakan bahwa tiga wilayah utama dari social skill adalah:

a. Affiliation (kerjasama)

b. Cooperation and resolution of conflict (kerja sama dan penyelesaian konflik)

c. Kindness, care, and affection/emphatic skill (keramahan, perhatian, dan kasih sayang)

Pellegrini (dalam Brewer, 1995) menyatakan tiga wilayah kecakapan yang harus dievaluasi dari social skill adalah:

a. Pengambilan peran sosial (social role taking)

b. Pemecahan masalah sosial

c. Kerjasama (interaksi kooperatif dengan yang lain)

Sementara social skill yang sudah dipisahkan dari personal skill dalam pembagian yang dilakukan Broling dapat dirinci bahwa social skill meliputi:

a. Komunikasi dengan orang lain

b. Tenggang rasa

c. Kepedulian pada sesama

d. Hubungan antar pribadi

e. Menemukan dan mengembangkan kebiasaan positif

f. Kemandirian, dan

g. Kepemimpinan

Dari berbagai uraian para ahli tersebut, terlihat bahwa aspek-aspek wilayah yang terdapat dalam definisi social skill banyak yang saling tumpang tindih, oleh karena itu dalam penelitian ini, definisi dari social skill disarikan menjadi tiga aspek utama, dengan mencantumkan aspek-aspek lainnya yang bersifat parallel 
sebagai sub-indikator dari ketiga aspek utama tersebut. Adapun aspek-aspek tersebut ialah:

1. Empati
a. penuh pengertian
b. tenggang rasa
c. kepedulian pada sesama

2. Afiliasi dan resolusi konflik
a. komunikasi dua arah/ hubungan an- tarpribadi
b. kerjasama
c. penyelesaian konflik

3. Mengembangkan kebiasaan positif
a. tata krama/kesopanan
b. kemandirian
c. tanggung jawab sosial

Beberapa aspek tersebut di atas yang akan menjadi inti observasi dalam penelitian tindakan ini.

\section{Peer Mediated Buddy Program}

Mediasi teman sebaya menurut Tyrell (2002) adalah: a process which endeavours to create a safe environment where disputant will be able to tell their stories and be heard by each other in the presence of a third party. Menurut pengertian ini mediasi teman sebaya berarti sebuah proses yang mengusahakan terciptanya lingkungan yang aman sehingga pihak-pihak yang bermasalah bisa menyampaikan unek-unek mereka dan saling mendengarkan dengan disertai kehadiran pihak ketiga. Jika diaplikasikan dalam kegiatan sosialisasi siswa dengan autisme hal ini berarti bahwa siswa dengan autisme memang secara nyata memiliki masalah dalam hal bersosialisasi. Hal ini dikarenakan siswa dengan autisme pada umumnya memang tidak bisa berteman seperti anak-anak lainnya. Kalaupun mereka mempunyai teman, mereka tidak mampu menjaga hubungan pertemanan tersebut hingga menjadi langgeng.

Peer mediated buddy program merupakan suatu program untuk meningkatkan kompetensi sosial bagi anak berkebutuhan khusus pada umumnya. Metode ini mengikutsertakan seluruh komponen di sekolah terutama muridmurid yang tidak mempunyai kebutuhan khusus dalam berinteraksi dengan murid yang berkebutuhan khusus. Pengikutsertaan siswa yang tidak berkebutuhan khusus dalam program ini dimaksudkan untuk memberi contoh bagi mereka yang berkebutuhan khusus. Hal ini disebabkan karena pada umumnya anak berkebutuhan khusus terutama siswa dengan autisme kurang atau bahkan sama sekali tidak mempunyai inisiatif dalam melakukan interaksi (Jones, 2002).

\section{METODOLOGI PENELITIAN}

Penelitian ini dilakukan dengan menggunakan metode penelitian tindakan kelas (PTK). Sedangkan desain intervensi tindakan yang digunakan adalah Model Kurt Lewin. Dalam model ini, ada 4 langkah penting dalam proses pelaksanaan tindakan yaitu (1) perencanaan, (2) tindakan, (3) observasi dan (3) refleksi. Keempat hal tersebut saling berhubungan satu sama lain se-hingga membentuk satu siklus dan dalam penelitian ini direncanakan ada 2 siklus yang bisa digambarkan sebagai berikut:

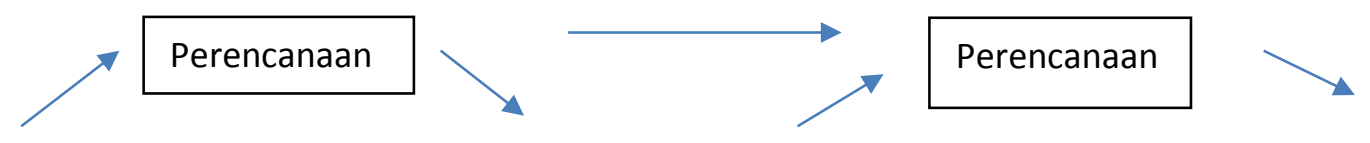




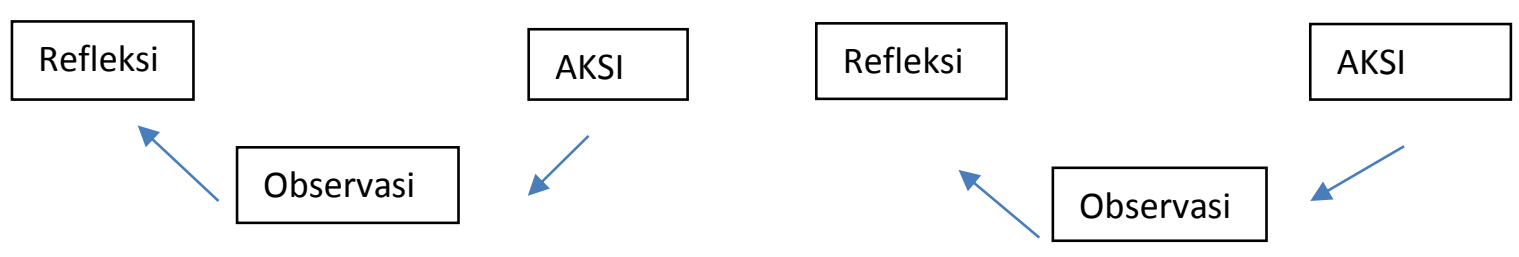

Gambar 1. Model Kurt Lewin

Penelitian ini dilakukan di SDN Kalibaru IV Kecamatan Medan Satria, Bekasi. Adapun instrumen yang digunakan adalah:

a. Observasi yang digunakan untuk mengumpulkan data yang berhubungan dengan pola hubungan sosial yang terjadi selama tindakan berlangsung antara siswa dengan autisme dan teman sebayanya yang ikut serta dalam penelitian ini.

b. Diskusi antara peneliti, guru kelas dan siswa yang menjadi teman siswa penyandang autis selama tindakan berlangsung.

\section{HASIL DAN PEMBAHASAN Deskripsi Data}

Berdasarkan hasil pelaksanaan tindakan dan penelitian yang telah dilakukan, berikut ini adalah penjabaran data hasil pemberian tindakan untuk mengajarkan socialisasi bagi siswa dengan autisme di SDN Kalibaru IV.

Sebelum mengadakan penelitian tindakan kelas, peneliti bersama guru melakukan pengamatan terhadap perilaku sosial yang dilakukan oleh siswa dengan autisme selama berada di dalam kelas ketika pembe-lajaran berlangsung dan di luar kelas selama waktu istirahat. Dari hasil pengamatan, tampak bahwa selama waktu istirahat tidak banyak hal yang dilakukan oleh 2 orang siswa penyandang autisme.
Andi selalu berada dalam kelas bersama ayahnya selama waktu istirahat, duduk berpindah dari bangku satu ke bangku yang lain terkadang pindah dari kelas yang satu ke kelas yang lain. Andi tampak tidak punya teman, walaupun ada temannya yang berusaha mendekati, dia kurang bisa merespon. Sedangkan Rita agak lebih sosial dibanding Andi. Rita mempunyai teman dan pergi belanja bareng temannya ke kantin dan kembali ke kelas bersama barang yang dibelinya lalu duduk dibangkunya kembali.

Ketika pembelajaran berlangsung Andi terkadang tiba-tiba berlari ke depan kelas tanpa tujuan sehingga mengagetkan guru lalu duduk kembali. Selama ini posisi tem-pat duduk Andi agak dibelakang karena badan Andi yang cukup besar agar tidak menghalangi temannya yang lain yang lebih kecil. Sementara tempat duduk Rita ada dideret bangku tengah paling depan karena ukuran badannya yang kecil. di dalam kelas ini ada 35 murid dengan 2 orang siswa dengan autisme dan tidak ada orang dewasa lain selain guru kelas. Guru tampak kurang memberikan perhatian kepada kedua siswa ini karena menurut pemikirannya guru kurang bisa memberikan perhatian khusus yang diperlukan oleh murid. Dan gurupun kekurangan bekal tentang perlakuan apa yang harus diberikan kepada kedua siswanya yang autisme.

Tabel 1. Data Hasil Pengamatan Pra-Siklus

\begin{tabular}{|l|l|l|}
\hline No. & Aspek yang diamati & \multicolumn{1}{c|}{ Keterangan } \\
\hline 1 & Komunikasi & $\begin{array}{l}\text { 1. Rita cukup bagus, ada komunikasi } 2 \text { arah }(5 \mathrm{X}) \\
\text { teramati }\end{array}$ \\
\hline
\end{tabular}




\begin{tabular}{|l|l|l|}
\hline & 2. Andi masih banyak membeo saja (4X) teramat \\
\hline 2 & Kerjasama & $\begin{array}{l}\text { 1. Rita bekerja sama dengan baik dengan teman } \\
\text { sebangkunya }(4 \mathrm{X}) \text { teramati } \\
\text { 2. Andi belum bisa bekerja sama dengan te-mannya }\end{array}$ \\
\hline 3 & Tata krama & $\begin{array}{l}\text { 1. Rita meminta ijin kepada guru ketika akan keluar } \\
\text { kelas pada saat pembelajaran } \\
\text { 2. Andi mengagetkan guru dan teman dengan berlari } \\
\text { menuju guru di depan }(3 \mathrm{X}) \text { teramati }\end{array}$ \\
\hline
\end{tabular}

\section{Deskripsi Data Siklus 1}

Berdasarkan pengamatan dan diskusi yang dilakukan oleh guru dan peneliti, maka guru dan peneliti bersepakat untuk membuat-kan suatu program yang diperkirakan bisa memudahkan guru dalam menangani siswanya yang autisme selama dikelas. Rancangan program yang sudah dibuat yaitu berupa rancangan program pembelajaran individual yang dikhususkan untuk anak. Rancangan ini bisa dilihat dihalaman lampiran.

\section{Tindakan}

$\begin{array}{rcc}\text { Peneliti } & \text { melakukan tindakan } \\ \text { dengan cara memberikan program }\end{array}$ sosialisasi bagi siswa dengan autisme baik di dalam maupun di luar kelas. Tindakan khusus yang diberikan adalah siswa dengan autisme diberikan teman secara khusus oleh guru. Teman ini dipilih oleh guru berdasarkan kriteria yang dimiliki oleh guru seperti teman yang kuat, pengertian, dan mau menjadi sukarelawan dalam mengajari temannya yang autisme. Sukarelawan yang terpilih ada 2 anak yaitu Iwan dan Rossi.

Teman sebaya yang sudah dipilih oleh guru kemudian dilatih cara-cara berinteraksi dengan siswa yang autisme. Dalam masa pelatihan siswa saling berpraktek ba-gaimana berteman dengan siswa yang autis. Keduanya bergantian menjadi siswa yang autis dan siswa biasa yang tidak mempunyai autisme. Kemudian kedua siswa tersebut di-terjunkan langsung berhubungan dengan te-mannya yang autisme baik di dalam maupun di luar kelas dengan pengawasan guru. Iwan dipasangkan untuk berteman dengan Andi sedangkan Rossi dipasangkan untuk berteman dengan Rita. Dalam kegiatan pembelajaran dikelas, Andi duduk bersebelahan dengan Iwan sedangkan Rita duduk bersebelahan dengan Rossi. Ketika saat istirahat Iwan dan Rossi diutamakan berteman dengan Andi dan Rita.

\section{Pengamatan}

Selama kegiatan pembelajaran di dalam kelas, guru menyampaikan materi seperti biasa dan siswa yang menjadi sukarelawan juga bersikap seperti biasa mendengarkan dan menyimak. Peneliti dan guru juga mengamati para sukarelawan yang sedang ditugasi menjaga, mengawasi dan menjelaskan materi pelajaran bila diperlukan. Demikian juga ketika saat istirahat, para sukarelawan ditugasi untuk menemani kemanapun siswa dengan autisme bermain.

Tabel 2. Data Hasil Pengamatan Siklus 1

\begin{tabular}{|l|l|l|}
\hline No. & Aspek yang diamati & \multicolumn{1}{c|}{ Keterangan } \\
\hline 1 & Komunikasi & 1. Rita memang komunikasinya cukup bagus \\
\hline
\end{tabular}




\begin{tabular}{|l|l|l|}
\hline & & $\begin{array}{l}\text { 2. Andi masih membeo dan kadang mengguna- } \\
\text { kan isyarat tangan }\end{array}$ \\
\hline 2 & Kerjasama & $\begin{array}{l}\text { 1. Rita saling berbagi kerta dengan sukarelawan } \\
\text { 2. Andi masih susah bekerja sama meskipun } \\
\text { sukarelawan sudah berusaha mengajarinya } \\
\text { ketika meminjam pensil }\end{array}$ \\
\hline 3 & Tata krama & $\begin{array}{l}\text { 1. Tidak ada masalah dengan Rita } \\
\text { 2. Andi merebut pensilnya dan masih berlari } \\
\text { walaupun hanya (2X) teramati }\end{array}$ \\
\hline
\end{tabular}

\section{Refleksi}

Peneliti, guru dan sukarelawan berdiskusi tentang perilaku siswa dengan autisme selama proses pertemanan yang disengaja dilakukan oleh sukarelawan dan siswa dengan autisme. Hasil diskusi menunjukkan bahwa salah satu sukarelawan yaitu Iwan merasa agak kewalahan berteman dengan Andi karena Andi masih terlalu susah diajak berkomunikasi. Iwan merasakan komunikasi mereka berdua kadang tidak nyambung karena cara Andi berbicara susah dimengerti oleh Iwan. Sebaliknya Rita dan Rossi tampak berhubungan seperti biasa, seperti anak seusia mereka pada umumnya. Rita memang mempunyai autisme tetapi dia masih bisa berkomunikasi seperti anak lainnya dan memang sepertinya tidak mengalami hambatan berkomunikasi.

Dari hasil pengamatan dan refleksi tindakan yang telah diberikan kepada siswa penyandang autis dan sukarelawan selama siklus pertama ini, tampak nya Andi memang membutuhkan perhatian yang lebih besar dari guru dan temannya dibanding Rita. Maka peneliti dan guru sepakat melanjutkan tindakan pada tahap berikutnya yang hanya dikhususkan kepada Andi dengan pemindahan Rossi juga dipasangkan dengan Andi. Jadi Andi akan mempunyai dua teman sekaligus yang siap membantunya.

\section{Deskripsi Data Siklus 2}

Berdasarkan hasil refleksi siklus pertama, maka dapat dilihat bahwa masih ada kendala yang masih belum bisa terselesaikan yaitu komunikasi diantara siswa dengan autisme dengan sukarelawan yang menjadi temannya. Sehingga tindakan dilanjutkan pada siklus kedua.

\section{Tindakan}

Tindakan yang diberikan pada siklus kedua yaitu adanya dua sukarelawan yang bekerja membantu seorang siswa dengan autisme. Dua sukarelawan ini dimaksudkan untuk saling bekerja sama bergantian menjaga dan menemani siswa dengan autisme. Ketika salah satu sukarelawan merasa tidak mampu lagi bertahan maka akan diganti oleh sukarelawan yang lain. Demikian seterusnya sampai dirasa tindakan kedua mencukupi. Dalam pembelajaran dikelas kedua sukarelawan ditempatkan pada posisi yang berdekatan dengan siswa dengan autisme.

\section{Pengamatan}

Selama kegiatan pembelajaran Andi masih berusaha lari ke arah guru di depan kelas namun dia bisa ditahan untuk tidak pergi oleh kedua sukarelawan yang duduk disamping kiri kanannya. dia hanya berdiri saja diantara dua temannya namun Andi kadang terlihat nekat akan naik bangku atau tempat duduknya.

\section{Refleksi}

Peneliti dan guru menganalisis perilaku yang ditunjukkan oleh Andi selama proses tindakan kedua diberikan. Tampaknya perilaku berlari menuju arah guru yang sering dilakukan oleh Andi mulai sedikit menghilang namun perilaku lainnya muncul seperti gerakan akan melompat dari tempat duduk. Berdasarkan beberapa pertimbangan 
dan pemikiran tentang perilaku apa yang akan muncul selanjutnya, penelitian ini dihentikan dan guru akan melanjutkan pemberian tindakan selanjutnya.

Berdasarkan data hasil pengamatan dan refleksi dalam pemberian tindakan pada siklus 1 dan 2 bahwa subyek penelitian mulai tahap awal memang mempunyai kemampuan komunikasi dan sosialisasi yang berbeda. Andi mempunyai karakteristik komunikasi yang lebih unik dibandingkan Rita sehingga dalam pemberian tindakan Andi memang perlu lebih banyak perhatian.

Pada hasil pengamatan pra siklus Andi terlihat lebih banyak membeo, komunikasi masih cenderung satu arah dan juga cenderung tidak sopan. Hal ini sebenarnya memang ciri-ciri anak atau siswa dengan autisme, yang menjadi ciri-ciri menonjol dalam hal kemampuan sosial. Sedangkan Rita sudah bisa berkomunikasi dengan baik walaupun terkadang masih kurang bisa dipahami. Setelah diberikan tindakan pada siklus pertama, kemampuan Rita terlihat sangat berbeda dibandingkan kemampuan awalnya. Rita mampu berkomunikasi dan bekerja sama dengan baik tetapi dia terkadang masih lupa tata aturan yang berlaku seperti memakai pensil harus ijin terlebih dahulu kepada pemiliknya.

Sementara itu, kemampuan komunikasi Andi masih belum sebagus Rita. Andi masih belum bisa menjaga konsistensi komunikasi dua arah, dalam artian ketika dia mulai berkomunikasi lalu ditanggapi oleh temannya, dia kebingungan bagaimana menjaga hal tersebut. Dalam hal kerja sama, sudah mulai tampak ada kemauan untuk melaksanakannya namun terkadang masih lebih memilih sendirian dalam mengerjakan tugas kelompok. Dalam hal tata krama atau kesopanan berperilaku, perilaku yang ditunjukkan semula yaitu berlari secara tibatiba ke arah guru pada saat guru menerangkan di depan kelas, sudah mulai berkurang. Namun, muncul perilaku baru yang dampak-nya tidak sebesar perilaku Dasar di DKI Jakarta. PLB UNJ Jakarta. sebelumnya. Dampak ini hanya mengenai beberapa siswa yang posisi duduknya berdekatan dengan Andi misalnya seperti para sukarelawan.

Perilaku yang dimunculkan sebagai akibat dari peredaman perilaku awal kemungkinan besar adalah karena kebiasaan atau kebutuhan siswa untuk mendapatkan rangsangan tertentu. Rangsangan itu mungkin diperlukan siswa untuk mengurangi kebosanan yang dirasakannya. Karena siswa tidak pernah mengatakan sesungguhnya mengapa perilaku itu muncul dan hampir selalu ada disetiap jam pelajaran. Selama ini guru jarang memberikan jeda waktu kepada siswa untuk berhenti sebentar dari aktivitas pembelajaran berlangsung dalam satu jam pertemuan.

\section{PENUTUP}

Data yang berhasil dikumpulkan selama proses pelaksanaan penelitian tindakan kelas di SD Kalibaru IV kemudian dievaluasi dan dianalisis. Dari keseluruhan data yang ada dapat disimpulkan bahwa peer mediated buddy program dapat digunakan sebagai alternatif model pembelajaran dalam meningkatkan kemampuan sosialisasi siswa dengan autisme.

Selama tindakan berlangsung ada perubahan perilaku siswa dengan autisme namun ada juga perilaku baru yang muncul. Perubahan perilaku pada siswa dengan autisme seperti perilaku berlari secara tibatiba pada saat proses pembelajaran sudah mulai berkurang namun digantikan dengan hanya berdiri di sekitar tempat duduk. Perubahan ini membawa ketenangan bagi seluruh kelas karena mereka tidak lagi dikagetkan oleh salah satu siswa. Guru pun menjadi lebih bisa menguasai kelas secara keseluruhan.

\section{DAFTAR PUSTAKA}

Abdurrahman, M. (2011). Sosialisasi Pendidikan Inklusi Bagi Sekolah

Depdiknas (Propinsi Jawa Barat). (2002). Life skill. Bandung: CV. Dwi Rama. 
Depdiknas (Tim Broad Based Education). (2002). Kecakapan Hidup; Melalui Pendekatan Pendidikan Berbasis Luas. Surabaya: Penerbit SIC.

Ginanjar, A. S. (2007). "Memahami Spektrum Autistik secara Holistik". (Disertasi). Program Pascasarjana Fakultas Psikologi Universitas Indonesia.

Handojo, Y. (2003). Autisma: petunjuk praktis dan pedoman materi untuk mengajar anak normal, autis dan perilaku lain. Jakarta: P.T. Bhuana Ilmu Populer, Kelompok Gramedia.

Jones, G. (2002). Educational Provision for Children with Autism and Asperger Syndrome: Meeting
Their Needs. London: David Fulton.

Rose, R., \& Grosvenor, I. (2001). Doing Research in Special Education: Ideas into Practice. London: David Fulton.

Sanjaya, W. (2009). Penelitian Tindakan Kelas. Jakarta: Kencana.

Schopler, E., Mesibov, G. B. (1995). Learning and Cognition in Autism. London: Plenum Press.

Stakes, R., \& Hornby, G. (2000). Meeting Special Needs in Mainstream Schools: A Guide for Teachers. Second edition. London: David Fulton.

Tyrell, J. (2002). Peer Mediation: A Process for Primary School. London: Souvenir Press. 